\title{
Kirpputoritavaran aika
}

\section{Svetlana Aleksijevitš: Neuvostoihmisen loppu. Kun nykyhetkestä tuli second handia. Tammi, 2018. Suom. Vappu Orlov. 697 s. ISBN: 978- 951-31-9878-7.}

Svetlana Aleksijevitšin (s.1948) viimeisimmän dokumentaarisen haastatteluromaanin suomennosta piti odottaa viisi pitkää vuotta. Ilman tekijälle vuonna 2015 myönnettyä Nobelin kirjallisuuspalkintoa emme ehkä olisi saaneet sitä koskaan, mutta vuonna 2018 se viimein ilmestyi Tammen Keltaisessa kirjastossa Vappu Orlovin taidokkaana käännöksenä.

Neuvostoihmisen loppu jatkaa Aleksijevitšin 1980-luvulla alkanutta "punaisesta ihmisestä" kertovaa Utopian äänet -sarjaa, jonka aiemmat suomennokset ovat Sodalla ei ole naisen kasvoja (2017) ja Tšernobylista nousee rukous (2015). Se on yhtä kunnianhimoinen kuin edeltäjänsä ja perustuu lukemattomille vuosina 1991-2012 tehdyille haastatteluille. Suurteoksen aihe on Neuvostoliiton romahdus ja sen seuraukset tavallisen ihmisen näkökulmasta. Haastateltavat ovat kotoisin eri puolilta neuvostovaltiota, ja heidän muisteloidensa kautta se kertoo paljon myös neuvostohistoriasta. Kerrottavaa ja muisteltavaa neuvostoihmisen elämässä totta vie riittää.

Svetlana Aleksijevitš sopii kertomaan monikansallisen valtion tuhosta ja sen seuraajien rappiosta, sillä hän on itse Ukrainassa syntynyt valkovenäläinen kosmopoliitti, joka kirjoittaa venäjäksi ja on asunut pitkään eri puolilla Eurooppaa. Kotimaassaan Valko-Venäjällä hänen kriittinen äänensä on vaiennettu eikä häntä ole siellä juuri julkaistu. Venäjälläkin Nobel-palkinnon taustalla nähtiin laajasti lännen tarve palkita Putinin hallinnon vastustaja. Aleksijevitšin tuotannon kirjalliset ansiot ovat kuitenkin kiistattomat. Kirjat kertovat vaikeista asioista tavallisen ihmisen näkökulmasta niin omaperäisellä tavalla, että hänen voisi sanoa luoneen aivan uuden kirjallisuuden lajin, jota yhteisöromaaniksikin on kutsuttu.

On helppo yhtyä siihen useasti toistettuun näkemykseen, että tämä romaani on tärkeää luettavaa jokaiselle, joka haluaa ymmärtää nykyVenäjää. 1990-luvun sekoilu neuvostovaltion raunioilla länsimaisen demokratian nimissä näyt- täytyy ihmisten tarinoissa sellaisena dystopiana, "nöyryyttävänä ja viheliäisenä elämänä" (s. 279), jota harva kaipaa. Kun "Yhdysvaltain salainen agentti" (s. 33) Gorbatšov "myi maan pizzasta" (s. 87), kommunismi selkäytimessään kasvanut sukupolvi menetti yhtäkkiä kaiken, johon se oli uskonut. Vanhemmat polvet pelkäsivät uutta Stalinia ja uutta sotaa, mutta nuoremmat puhuvat Neuvostoihmisen lopussa Stalinista jo positiivisemmin. Kuluneella vuosikymmenellä kehitys on jatkunut. Viimeisimmässä Levada-keskuksen kyselyssä Staliniin ihaillen, kunnioittaen tai ymmärtäen suhtautuu jo joka toinen, kun kaunaa, pelkoa tai vihaa tuntee vain joka seitsemäs.

"Jotta voisi tuomita Stalinin, pitäisi tuomita omat sukulaisensa ja tuttavansa" (s. 49), selittää yksi. "Koko meidän onnettomuutemme on se, että meillä pyövelit ja uhrit ovat niitä samoja ihmisiä," (s. 393) sanoo toinen. Tähän tiivistyy romaanin läpi tunkeva kysymys uhreista ja pyöveleistä. Aleksijevitšin mukaan totalitarismi ja pakkotyöleirit turmelevat niin pyövelin kuin uhrinkin. Sen seurauksista kärsitään nyt ItäUkrainan sodassa, sillä neuvostomenneisyyden perillisten on vaikea kuvitella muita konfliktinratkaisumalleja kuin voimankäyttö.

Toistuva motiivi Neuvostoihmisen lopussa on, että "elettiin ihan hyvin, ennen kuin kapitalismi tuli" (s. 473). Neuvostoajan viimeiset vuosikymmenet näyttäytyvät aikana, jolloin luettiin yhdessä Puškinia ja elettiin vailla huolia ystävyydessä naapureiden kanssa kansallisuuksista välittämättä. 1980-90-luvun vaihteen etnisistä väkivaltaisuuksista romaanissa on monta riipaisevaa tarinaa. Azerbaidžanissa poltetaan armenialaisia, Armeniassa nyljetään azerien nahkoja, öisessä Suhumissa karannutta apinaa ensin haavoitetaan abhaasina ja sitten ammutaan georgialaisena, Venäjällä poliisit hakkaavat tadžikkeja, Tadžikistanista venäläiset ajetaan pois. Näin nämä asiat koetaan, ja moni päätyy itsemurhaan. Moskova täyttyy vihatuista "mustista", jotka vielä hetki sitten olivat kantaväestön maanmiehiä. "Moskova, sinä et välitä siitä, rakastetaanko sinua vai ei" (s. 596), toteaa tekijä, jonka omat kommentit erottuvat tekstistä kursiivilla kirjoitettuina. 
On kuitenkin väärä tulkinta, että romaani kaihoaisi jonkinlaiseen menetettyyn utopiaan. Selväksi käy, että moni ei ollut tyytyväinen elämään Neuvostoliitossakaan. "Stalin valeli tämän maan verellä, Hruštšov kylvi siihen maissia, ja Brežnevistä kaikki tekivät pilaa” (s. 381), tiivistää yksi. Gorbatšov on silti kansan pahin petturi, vaikka kauas ei jää Jeltsinkään.

Yhdessä tarinassa kuolee mummo. Tyttärellä ja lapsenlapsilla ei ollut rahaa hautajaisiin, ei ruumiin kuljettamiseen ruumishuoneelle, ei edes kuolintodistukseen. Niinpä tytär asui lapsineen viikon samassa asunnossa vainajan kanssa. He pyyhkivät ruumista kaliumpermanganaatilla ja peittivät sen märillä lakanoilla, sulkivat ikkunat tiukasti ja tiivistivät ovet märillä peitteillä. Jostain ilmaantuneet roistot maksoivat hautajaiset ja valtasivat asunnon. Äiti tyttärineen jäi asunnottomaksi. Kerran äiti sai hetkeksi työtä löydettyään aidasta ilmoituksen: "Halutaan siivooja, jolla on korkeakoulututkinto" (s. 487).

Romaanin venäjänkieliseen otsikkoon Vremja sekond hend - ja suomennoksen alaotsikkoon on päätynyt kielikuva "second handin ajasta". Sen voisi suomentaa vaikkapa kirpputoriajaksi, sillä se viittaa 1990-luvun alussa kaduille ilmestyneisiin myyntikojuihin, joissa neuvostomenneisyys eri muodoissaan oli kaupan: Leninin rintakuvia, kunniamerkkejä, sotilaspukuja, punatähtisiä koppalakkeja, punalippuja ja muuta totalitarismin aikakauden esineistöä. Neuvostojumalista oli tullut metalliromua. Veistä käänsi haavassa se, että hinnat olivat dollareissa. Yksi haastateltava valitti miliisille, mutta tämä sanoi, että eivät he voi puuttua kuin huumausaineiden tai pornografian myyntiin. "Eikö puolueen jäsenkirja kymmenellä dollarilla muka ole pornografiaa?" (s. 139).

Niin hienosti kuin Aleksijevitš nostaakin tavallisen kansalaisen näkökulman esiin, eivät Neuvostoihmisen lopun ansiot siihen lopu, sillä äänen saavat myös entiset vallanpitäjät. Romaani jäljittää höyrypatteriin hirttäytyneen marsalkka Ahromejevin tilityksiä elokuun vallankaappauksen motiiveista. Yksi nimettömänä pysyvä entinen Kremlin työntekijä taas avaa, miten alhaaltapäin tapahtuvalle vallankumoukselle murtumattomaksi rakennettu valtio murennettiin ylhäältä käsin. Suunvuoron saa myös insinööri, joka omien sanojensa mukaan oli "yksi niistä idiooteista, jotka puolustivat Jeltsiniä” (198). Aleksijevitšilla on taito koota äänten kakofonia yhdeksi suureksi sinfoniaksi.

Nyt suomennettu romaani saattaa olla Utopian äänten dystooppinen loppu. Aleksijevitš on sanonut jatkavansa 1990-luvulla salaperäisellä työnimellä "Ikuisen metsästyksen ihmepeura" ("Tšudnyi olen vetšnoi ohoty") aloittamaansa kirjaa rakkaudesta. Nähtäväksi jää, onko rakkaus Valko-Venäjän historian toiselle nobelistille utopia vai dystopia.

Mika Perkiömäki

\section{Itäinen Eurooppa demokratian uusien trendien eturintamassa?}

\section{Katalin Miklossy \& Jouko Nikula (toim.): De- mokratian karikot. Itäinen Eurooppa suuntaa etsimässä. Helsinki, Gaudeamus, 2018. 237 s. ISBN: 9789524954853.}

Katalin Miklossyn ja Jouko Nikulan toimittama Demokratian karikot. Itäinen Eurooppa suuntaa etsimässä (Gaudeamus) on mielenkiintoinen paketti Itäisen Euroopan nykytilasta, mutta herättää myös monta kysymystä Euroopan, demokratian ja markkinatalouden tilasta laajemmin maailmassa. Kirja rakentuu kolmelle väitteelle. Ensinnäkin itäistä Eurooppaa tulee tarkastella alueena, jolloin koko alueen yhteiset trendit erottuvat yksittäisten maitten tapahtumista. Toiseksi itäisen Euroopan alueellinen sijainti aikaisemmin
Venäjän ja Neuvostoliiton imperiumin ja LänsiEuroopan välissä on ollut merkityksellisempi alueen sisäiselle kehitykselle kuin on aina haluttu ymmärtää. Kolmanneksi alueen nykytilan ymmärtämiseksi on otettava huomioon se, miten historian eri vaiheet vaikuttavat nykypäivään. Historia on täynnä katkoksia ja siksi on tärkeä eritellä, mitkä historialliset jatkumot kulloinkin saavat enemmän painoarvoa nykyisyyden ymmärtämisessä.

Kirjan kolme ensimmäistä lukua esittelevät itäisen Euroopan historiaa, suuria poliittisia kehityskaaria sekä talouden muutoksia. Näissä myös esitetään muutamia teoreettisia viitekehyksiä, joiden kautta lukija voi jäsentää artikkelikokoelman antia. Miklossy lähestyy itäisen Euroopan 